\section{Putting flesh onto the bones}

\section{Malcolm C. McKenna}

Mammal Evolution: An Illustrated Guide. By R. J. G. Savage and M. R. Long. British Museum (Natural History)/Facts on File:1986. Pp.264. £17.50, \$35.

FOR most fossil mammals, dry bones have been brought to life inadequately by professional palaeontologists. Among extinct animals, the dinosaurs have stolen most of the limelight, and much of the rich store of research-level information about mammalian evolution reaches the public only as background material to the latest discoveries of rival anthropologists. Although there is a great story to tell about mammalian evolution, and a great opportunity to discuss how the scientific method can be applied to the subject, the good books on mammalian evolution over geological time have long been out of print or are badly outdated. Palaeontologists are bombarded by requests about the appearance in life of extinct mammals, and how they changed with time, but we possess few attempted reconstructions to show to the public; those that we do have are generally clones of previous attempts. Although professionals sometimes wince at reconstructions of fur colour patterns and other indefensible extrapolations from what is actually preserved in the fossil record, such images are undeniably useful for non-specialists. Life is breathed into the subject.

In this book, Michael Long (artist) and R. J. G. Savage (palaeontologist) do bring

\title{
Edges of knowledge
}

the evolution of mammals to life, from their poorly known beginnings in the Mesozoic to the richly known record of the Cenozoic. The book combines evocative restorations with spritely text. Many of the illustrations are new and plausible reconstructions of unfamiliar beasts; others clearly owe a debt to previous renderings. Some are outrageously funny, such as the human-faced Thylacosmilus nicki, or the contrite Gigantopithecus and wistful Lystrosaurus. The text is well written and pitched at the right level to maintain interest, mixing solid information with interesting references and speculation. It starts with a quotation from Shelley's Prometheus Unbound and ends with Dale Russell's silly illustration of a hypothetical ET-like "dinosauroid hominid". Between these there is much food for thought for non-specialists. There are a number of minor errors, but these can be weeded out for the future editions that will surely follow.

Our understanding of mammalian evolution is itself evolving, as more complete specimens are found and, perhaps more importantly, as methods of analysis improve. Although I found the book rewarding, one criticism is that the authors have missed the chance to move up from Kiplingesque scenarios to epistemologically more mature ground. After all, the British Museum (Natural History) is leading the way in injecting scientific method into its exhibits about evolution. To complement that effort, the book could have moved from exciting animals to greater emphasis on exciting problems.

Malcolm C. McKenna is Frick Curator in the Department of Vertebrate Paleontology, American Museum of Natural History, New York New York 10024, USA.

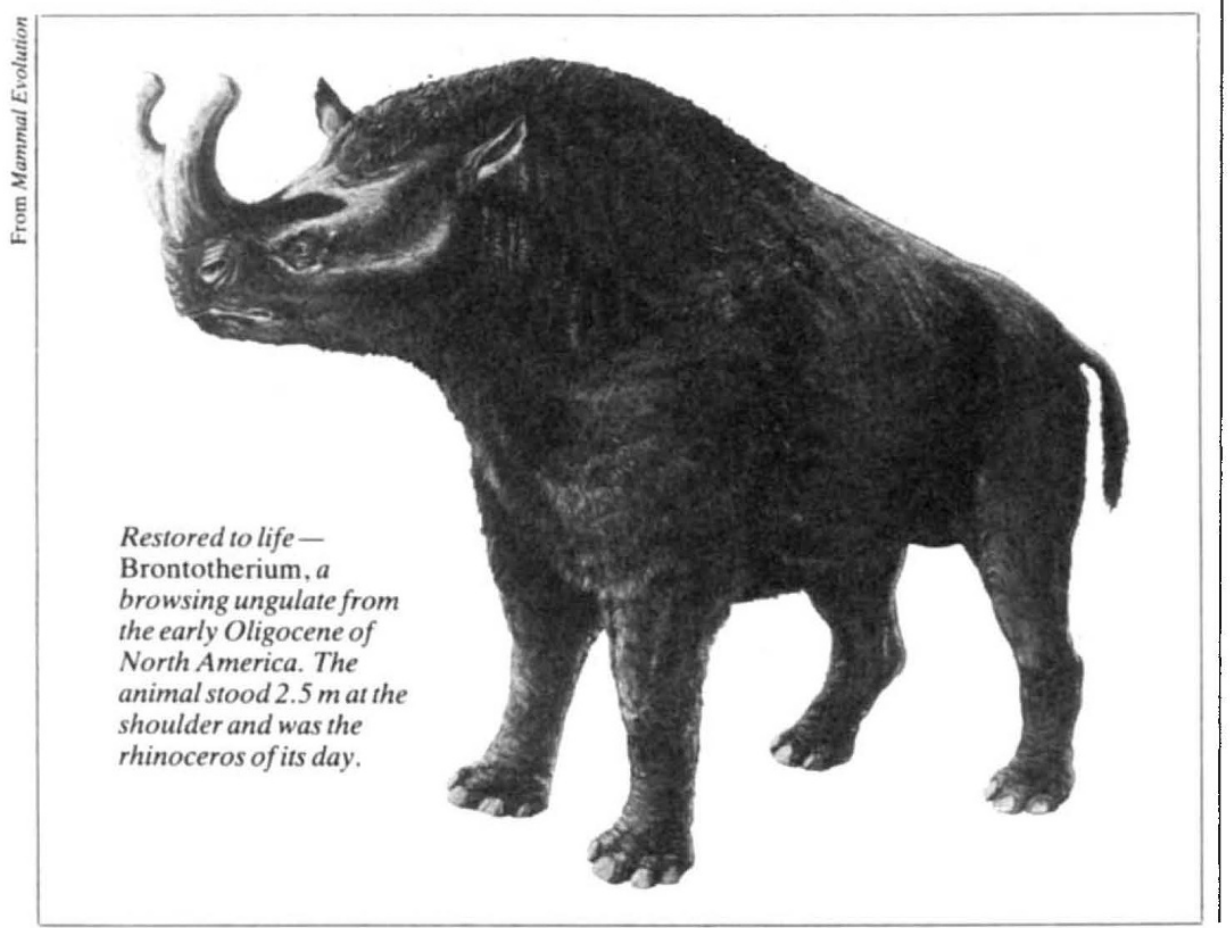

\section{A. Hallam}

Controversy in Victorian Geology: The Cambrian-Silurian Dispute. By James A. Secord. Princeton University Press:1986. Pp.363. \$49.50, £33.10.

Though geologists for the most part do not exhibit much interest in the history of their subject, there are few, in Britain at least, who do not know a little about the battle of those nineteenth-century giants Adam Sedgwick and Roderick Murchison. What had begun in friendly collaboration gradually developed over a quarter of a century into a bitter feud resulting in mutual estrangement. Like many stories known only in outline, however, the Cambrian-Silurian controversy is surrounded by misconceptions or is not properly appreciated for its most essential characteristic: it was a debate about the proper way to conduct a particular type of science, rather than a mere territorial or priority dispute. With an abundance of letters, notebooks and accounts of meetings available for study, the subject has long been ripe for the sort of book that Secord has written, a detailed, scholarly analysis using modern insights into the sociology of Victorian science.

Through the application of the novel technique of correlating strata by fossils, by the early 1830 s great strides had been made in establishing both a relative timescale and producing a reliable geological map for the structurally uncomplicated younger rocks in Britain. The ancient "grauwacke" or transition rocks of Wales, however, were a geological terra incognita that provided a kind of new frontier challenge. Sedgwick started work in North Wales and Murchison in the Welsh Borders, which led respectively to their proposing the Cambrian and Silurian systems, with a mutually agreed boundary being established. After some years it became apparent that Sedgwick's Upper Cambrian corresponded with Murchison's Lower Silurian. The newly created Geological Survey adopted Murchison's classification and Sedgwick became increasingly isolated. But the turning point came with the recognition of a major unconformity between Murchison's Lower and Upper Silurian, and the discovery of "primordial" fossils at a stratigraphic level well below that in which anything had previously been found. In the 1850 s and 1860 s many leading geologists switched their allegiance to a three-fold classification of what we now call the Lower Palaeozoic, and the dispute effectively came to an end in 1879 when Charles Lapworth proposed the term Ordovician for Murchison's Lower Silurian.

Secord argues that "Cambria" and 
"Siluria" were conceived of and valued as labels for scientific properties and signals of accomplishment in the quest for originality, with Sedgwick fighting for the Cambrian as a compensation for his failure to complete a major geological book and the more urbane but autocratic Murchison exhibiting a kind of imperialist expansionism in spreading the Silurian both across the world and down to the base of the oldest recognizable fossil-bearing rocks. Whereas Murchison laid emphasis on fossils as the only sound basis for correlation, Sedgwick thought it imperative to establish rock sections with a variety of physical criteria in a way that exemplified the principles of induction that he taught his students at Cambridge; the vehement defence of his Cambrian territory was a kind of moral crusade for the principles of truth and justice as he saw them.

Throughout the dispute, we perceive a characteristic Victorian preoccupation with facts and their classification, rather than with the testing of theories involving process and time. Secord brings out clearly the influence of various social factors in affecting the position which particular people adopted, such as personal com- petition, the character of the institution to which they belonged, the opportunities for professional advancement and so on. Furthermore, the nature of the underlying assumptions, and indeed the whole conceptual framework, had an influence on what were recognized as "objective" facts.

Secord adopts a straightforward narrative approach and has produced a wellwritten, sometimes absorbing account which demonstrates convincingly the heuristic value of controversy in promoting scientific advance. What I missed, however, was more of the authentic voice of the leading disputants. Sedgwick was by all accounts a lively and engaging, if somewhat choleric, person who expressed himself with great force and eloquence. It would have been gratifying to see more evidence of this through the inclusion of extended extracts from his correspondence and notebooks, and to contrast it with the more restrained but dogmatic tone of Murchison who is likewise poorly served by quotation.

A. Hallam is Lapworth Professor of Geology, University of Birmingham, PO Box 363, Birmingham B15 2ET, UK.

\section{Top people read...}

John C. Marshall

The Harvard Guide to Influential Books: 113 Eminent Harvard Professors Discuss The Books That Have Shaped Their Thinking. Edited by C. Maury Devine, Claudia M. Dissel and Kim D. Parrish. Harper \& Row:1986. Pp.300. Hbk\$18.95; pbk\$7.95.

What do Rats, Lice, and History, Dynamic Administration, Amateur Telescope Making and the Adventures of Pinocchio have in common? The answer is that each was chosen by one of " 113 eminent Harvard professors", who here "discuss the books that have shaped their thinking". I emphasize "one" because the most striking characteristic of The Harvard Guide to Influential Books is how few choices the contributors hold in common. Between them, the distinguished professors refer to some 560 works, most of which I (and you) have not read. I accordingly thought that the best way to educate myself would be to pick out the really influential books, say those that at least five contributors mention. We are now left with The King James Bible (seven listings), War and Peace (six) and The Republic, The Federalist Papers and The Adventures of Huckleberry Finn (five each). If authors with listings for multiple books are counted, Winston Churchill, Sigmund Freud, Thomas Mann, William Shakespeare and Max Weber just manage to creep in.
To catch a scientist we must drop to four citations for On the Origin of Species. Physicists and chemists are conspicuous mainly by their absence. No one seems to have been much impressed by Galileo, Newton or Max Planck, nor inspired by Lavoisier, Dalton or Mendeleev. Gone are the days when eminent Harvard mathematician Tom Lehrer concluded his song of the elements with the immortal lines: "These are the only ones of which the news has come to Harvard. There may be many others but they haven't been discarvard". Einstein is cited once, by Nicolaas Bloembergen, for his 1938 book (with Infeld) Physik als Abenteuer der Erkenntnis. Other physicists enter either as philosophers of science or as (proto-) molecular biologists. (No prizes for guessing Schrödinger's What is Life? in the latter category.) Mathematicians figure only as statisticians and "decision theorists" (vide Von Neumann and Morgenstern's Theory of Games and Economic Behavior). No one's life was made more (or less) uncertain by Heisenberg's principle; no one was converted to existentialism by Gödel's theorem.

In part, the obvious omissions result from the editors' admonition that contributors should not merely recite "Western Civilization's Great Books", but rather tell of the printed matter that actually influenced them. Much of the compilation's charm arises from this constraint. Thus architect Moshe Safdie engagingly praises Rudofsky's Architecture without Architects; E.O. Wilson confesses that, at age sixteen, Lysenko's Heredity and Its Varia- bility enchanted him with its "radical and effective challenge to conventional science"; and, best of all, Mary Chatfield cites "any good cookbook" as evidence that "the rational is still achievable in the most chaotic of worlds". Occasionally one is perplexed by the reasons given for a particular choice. Historian Bernard Bailyn admires Ernest Jones's Life and Work of Sigmund Freud as "a morality tale of... heroic achievements", but spoils the effect by concluding "And it happens to be true". For psychologist Richard Herrenstein, The Trial and The Castle "captured the lunacy and futility of individuals struggling with bureaucracies". Poor Frank: when will people learn that Kafka is not kafkaesque?

None of the faculty has been shaped by the Talmud, the Life of the Buddha or the Koran; indeed, insofar as the "East" (either near or far) exists at all for the contributors it is usually in the form of economic competition with Japan (vide, for example, Japan as Number One: Lessons for America). Piety comes in predominantly paternal form, although $\mathrm{Di}$ ana Eck (a professor of comparative religion) writes thoughtfully about Mary Daly's Beyond God the Father: Toward a Philosophy of Women's Liberation, and Sidney Verba (director of the University Library) recommends Chaim Grade's memoirs of the shtetl in Rabbis and Wives. Philosophy tends to the conservative; when Aristotle, Hayek, Hegel, Mill and Popper turn up it is more for their politics than their metaphysics. The spirit of the Law School, the Business School and the Kennedy School of Government dominates the enterprise. Das Kapital receives a derisory two votes, The General Theory of Employment, Interest, and Money scores zero. Proudhon, Bakunin and Prince Kropotkin fail to make the grade, whilst $E x$ plaining the Cuban Missile Crisis, America's Competitive Edge and Machiavelli's Prince get straight A's. Balance is only marginally restored by educationalist Francis Keppel, who cites The New York Times, a choice that serves to remind us that Britain has not had a decent daily since the Manchester Guardian dropped the Manchester.

Reviewers often decline to take compilations such as this seriously. Au contraire, I found the Harvard Guide fascinating and deeply informative. My only regret is that space was not found for the book-lists of eminent Harvard secretaries - the people who really keep an institution moving. I eagerly anticipate a series of such volumes from major universities. They would provide a far better guide to advising one's children on which centres of higher learning to apply to than do the usual bland prospectuses.

John C. Marshall is in the Neuropsychology Unit, part of the Neuroscience Group at the Radcliffe Infirmary, Oxford $O X 26 \mathrm{HE}, U K$. 